\title{
Jelka pl. Labaš Blaškovečka - prva predstojnica Škole za sestre pomoćnice u Zagrebu
}

\section{Jelka pl. Labaš Blaškovečka - first superintendent of the School for Nurses in Zagreb}

Dubravka Trgovec', Sanda Franković ${ }^{2}$

1Škola za medicinske sestre Vinogradska, Vinogradska cesta 29, 10000 Zagreb, Hrvatska, e-mail: dubravka.trgovec@gmail.com

2Sanda Franković, bacc. med. techn., prof. sociologije, Škola za medicinske sestre Mlinarska, Mlinarska 34, 10 000Zagreb, Hrvatska, e-mail: sfrankovic@ gmail.com

\section{Sažetak}

Uvod: Škola za sestre pomoćnice u Zagrebu od svog osnutka 1921. godine uz ravnatelja škole ima i sestru predstojnicu. U radu se pokušala učiniti rekonstrukcija školovanja i rada Jelke pl. Labaš Blaškovečka, prve nadstojnice u Školi za sestre pomoćnice u Zagrebu. Učinjen je i kratak osvrt na njezino djelovanje u družbi Kćeri Božje ljubavi kojoj se pridružuje nakon odlaska iz škole.

Metode: Rekonstrukcija podataka temeljila se na fondovima Hrvatskog državnog arhiva (HDA) i Državnog arhiva u Karlovcu. Korišteni su podaci iz arhiva Provincije Božje providnosti Družbe Kćeri Božje ljubavi. Kao dopuna arhivskim izvorima korišteni su do sada objavljeni radovi na obrađenu temu.

Rezultati: Uvidom u arhivsku građu i pregledom publikacija opisano je školovanje Jelke pl. Labaš Blaškovečka u Višoj djevojačkoj školi u Karlovcu, nastavak obrazovanja i djelovanje u Bolnici Crvenog križa Rudolfinerhaus u Beču. Opisani su uvjeti imenovanja za prvu nadstojnicu Škole za sestre pomoćnice u Zagrebu i njezin rad u vrijeme obavljanja te funkcije. Navedena su mjesta i pozicije na kojima je djelovala u Družbi Kćeri Božje ljubavi.

Zaključak: Obrazovanje i iskustvo koje je Jelka pl. Labaš stekla radeći u Rudolfinerhausu u Beču primjenjivala je u izobrazbi sestara u školi za sestre pomoćnice u Zagrebu. Svojim je radom doprinijela organizaciji škole u prvim godinama njenog djelovanja. Za šire razumijevanje njezina rada nakon odlaska iz škole u Družbu Kćeri Božje ljubavi bilo bi potrebno dodatno istražiti pismohranu Družbe.

Ključne riječi: Jelka Labaš, Škola za sestre pomoćnice u Zagrebu, Rudolfinerhaus, Družba Kćeri Božje ljubavi, povijest sestrinstva

Kratak naslov: Jelka pl. Labaš Blaškovečka

\section{Abstract}

Introduction: School for nurses in Zagreb since its founding in 1921, alongside the school principal, also had a nursing superintendent. The paper tried to reconstruct the schooling and work of Jelka Labaš Blaškovečka, the first superintendent at the School for Nurses in Zagreb. A brief review shows her work in the Daughters of Divine Charity (international congregation of Roman Catholic religious sisters), which she joined upon finishing school.

Methods: The reconstruction of the data was based on funds from The Croatian State Archives and The National Archives in Karlovac. Data from the archive of the Province of God providence of the Daughters of Divine Charity was used. Published papers on the topic have been used as an addition to archival sources. Results: The insight into the archives and examination of publications was used to describe the schooling of Jelka pl. Labaš Blaškovečki at the Girls' High School in Karlovac, as well as a continuation of her education and work in Red Cross Hospital at the Rudolfinerhaus in Vienna. Terms of appointment for the first superintendent of the School for Nurses in Zagreb and her work then is described. Her workplaces and job positions in the Daughters of Divine Charity are listed.

Conclusion: Jelka pl. Labaš applied her education and experience that she acquired while working at the Rudolfinerhaus in Vienna in training nurses at the School for Nurses in Zagreb. With her work, she contributed to the organization of the school in the first years of its operation. For a broader understanding of her work in the Daughters of Divine Charity, further examination of its archives would be necessary.

Keywords: Jelka Labǎ̌, School for nurses, Rudolfinerhaus, Daughters of Divine Charity, history of nursing

Short title: Jelka pl. Labaš Blaškovečka

\section{Uvod}

Razdoblje nakon Prvog svjetskog rata obilježeno je pojavom potpuno nove zdravstvene politike koja je u središte zanimanja stavila javnozdravstvene probleme i preventivu.

\section{Introduction}

The period after World War I had been marked by the appearance of a completely new health policy that focused on public health issues and prevention of the problems. Dete- 
Teško zdravstveno stanje populacije nakon rata tražilo je nov način djelovanja, mnogo širi i kompleksniji od onog kakav je bio poznat do tada. Velik broj ljudi na području novonastale Kraljevine SHS stradao je od zaraznih bolesti poput tifusa, španjolske gripe i tuberkuloze. Teška socijalna i gospodarska situacija dodatno je pogodovala širenju bolesti i nastanku epidemija. U cilju sprečavanja epidemija te kontrole postojećih bolesti, uviđa se nužnost oblikovanja jedinstvenog javnozdravstvenog programa koji će uspostaviti djelotvornu higijensko-epidemiološku i preventivno-profilaktičku službu. Trebalo je stvoriti sustav u kojem bi medicinska pomoć bila dostupna širokim slojevima društva, a ne samo imućnima i onima koji su stanovali u gradskim središtima [1].

Po povratku iz inozemstva 1920. godine u Zakladnoj bolnici u Zagrebu dr. Vladimir Ćepulić osniva Odjel za tuberkulozu te je imenovan za primariusa i šefa tog odjela. $\mathrm{Na}$ temelju stečenih saznanja u inozemstvu predlaže tadašnjem Zdravstvenom odsjeku za Hrvatsku, Slavoniju i Međimurje osnivanje prvog antituberkuloznog dispanzera u Hrvatskoj jer u našoj sredini dispanzer kao zdravstvena ustanova do tada nije postojao. U srpnju 1921. godine u Zakladnoj je bolnici osnovao prvi Antituberkulozni dispanzer u sjevernoj Hrvatskoj, a potom širi mrežu osnivanjem pomoćnih dispanzera u zagrebačkoj okolici (Šestine, Bistra i Kašina). Znajući da je za rad dispanzera na terenu, osim liječnika, nužno potrebno i dodatno kvalificirano osoblje, iste godine predlaže i osnivanje Škole za sestre pomoćnice u Zagrebu [2, 3].

Predlaže Zdravstvenom odsjeku za Hrvatsku, Slavoniju i Međimurje nacrt i naučnu osnovu za školu, a tadašnji načelnik Ministarstva zdravlja dr. Andrija Štampar i šef zdravstvenog odsjeka dr. Josip Lochert, podržali su taj prijedlog te je 15. siječnja 1921. godine počela s radom prva Škola za sestre pomoćnice u Zagrebu [4].

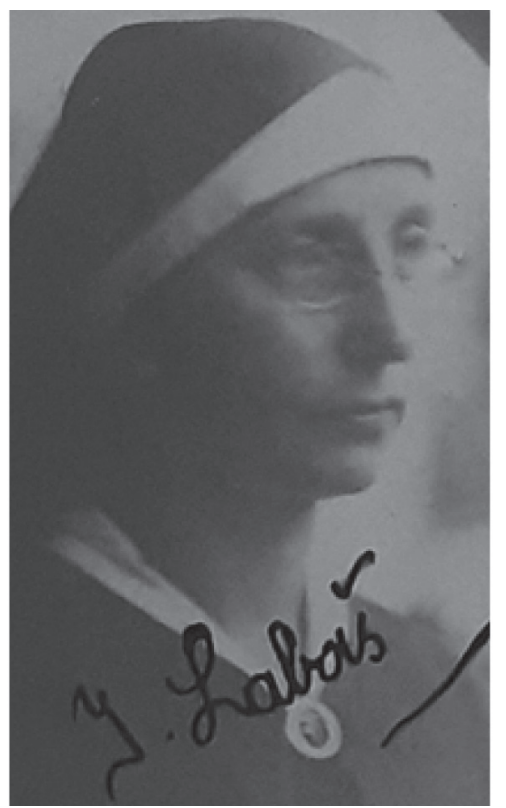

SLIKA/FıgURE 1. Jelka pl. Labaš Blaškovečka. Izvor: HR-HDA-890. Službenički list, Jelka Labaš / Jelka noble Labaš Blaškovečka. Reference: HR-HDA-890. Tribunal papers, Jelka Labaš riorating the health conditions of the population during the post-war times required a new kind of approach that would be broader and more complex than the one before. The large number of people living in the newly created Kingdom of Serbs, Croats, and Slovenes suffered from infectious diseases such as typhus, Spanish flu, and tuberculosis. The difficult social and economic situation had contributed to the spreading of diseases and outbreaking of epidemics.

Aiming at the prevention of epidemics and keeping the existing illnesses under control, the necessity to form a unique public health program was perceived. Its role should have been to establish efficient hygienic-epidemiologic and preventive-prophylactic services. It was important to create a system in which medical care would be accessible to a wide scope of population and not only to the rich and those living in city centers [1].

After he had returned from abroad in 1920, doctor Vladimir Ćepulić founded a Tuberculosis ward in Treasury/Foundation hospital in Zagreb and was its chief physician and the leading MD of the Ward. Based on his knowledge acquired in other countries, he suggested to the contemporary Health Department for Croatia, Slovenia, and Međimurje region to establish the first Anti-tuberculosis dispensary in Croatia because in our environment the dispensary as a health institution did not exist until then. In June 1921, he started with the first anti-tuberculosis clinic within Foundation Hospital serving the region around and in the vicinity of Zagreb (Šestine, Bistra, and Kašina). Knowing that the work in the clinic and among infected people requires not only well-educated doctors but also the necessary highly qualified additional personnel, he also proposed the founding of the school for nurses in Zagreb [2, 3].

Doctor Ćepulić suggests to the Health Care Department for Croatia, Slovenia, and Međimurje region the plan and scientific basis for the founding of the school. The current commissioner of the Ministry of Health, doctor Andrija Štampar, together with the chief of the Health Department, doctor Josip Lochert, supported his suggestion and therefore in January 15, 1921, the first school for nurses in Zagreb started working [4].

When established, the school had been situated on the premises of the Foundation hospital under the state management in the city of Zagreb. Doctor Vladimir Ćepulić was nominated for its principal. Jelka noble Labaš Blaškovećka was named the superintendent, and she was also the first formally educated nurse in Croatia. Her life, education, and her work during the initial years of the school's existence are poorly described in both reference books and monographs of the School for Nurses Mlinarska. That is one of the reasons why the authors of the article tried to reconstruct the basic information concerning her youth and schooling period, the time she spent in school as its superintendent, together with her activities in the congregation of Daughters of the Divine Charity.

\section{Early life, education, and work in the Red Cross Hospital Rudolfinerhaus}

Jelka noble Labaš Blaškovečka was born in April 19, 1886 in Karlovac as a daughter of Janko noble Labaš Blaškoveči 
Prilikom osnutka Škola je smještena u prostore Zakladne bolnice pod državnom upravom u Zagrebu, a dr. Vladimir Ćepulić imenovan je ravnateljem škole. Jelka pl. Labaš Blaškovečka bila je imenovana prvom predstojnicom i ujedno je bila prva školovana medicinska sestra u Hrvatskoj. Njezin život, školovanje i djelovanje u prvim godinama rada škole vrlo su oskudno opisani u literaturi i u monografijama Škole za medicinske sestre Mlinarska. Iz tog su razloga autorice odlučile pokušati rekonstruirati osnovne podatke o njezinoj mladosti i školovanju, vremenu koje je provela u školi u svojstvu predstojnice i njezino djelovanje u Družbi Kćeri Božje ljubavi.

\section{Mladost, školovanje i rad u Bolnici Crvenog Križa Rudolfinerhaus}

Jelka (Jelena) pl. Labaš Blaškovečka rođena je 19. travnja 1886. godine u Karlovcu kao kći Janka pl. Labaš Blaškovečkog i Vilme rođene barunice Salis-Seewis [5]. Otac je po zanimanju bio perovođa ${ }^{1}$. U krsnom se listu navodi da je vjera roditelja rimokatolička, a mjesto stanovanja predgrađe Karlovca. Krštena je 25. travnja 1886. godine u Župi Maria Sniežna u Dubovcu. Kumovi na krštenju bili su Emanuel pl. Vraniczany-Dobrinović, vlastelin u Severinu, i njegova supruga Jelena [6]. Jelka je rođena kao prvo od desetero djece i imala je dvoje polubraće iz očeva prvog braka. Iz podataka o mjestu rođenja braće i sestara može se zaključiti da je obitelj živjela u Samoboru, Virovitici, Zeuggu i na kraju u Varaždinu gdje su roditelji i preminuli [7].

Jelka Labaš pohađa Višu djevojačku školu u Karlovcu. Iz podataka koji se nalaze u svjedodžbama od petog do osmog razreda vidljivo je da je u vrijeme školovanja živjela u Karlovcu na Zrinjskom trgu, a otac je u to vrijeme bio kraljevski kotarski predstojnik u Senju [8]. Školu je završila 29. lipnja 1901. godine [9].

Dozvolom Kraljevske zemaljske vlade, Odjela za bogoštovlje i nastavu, 1873. godine osnovana je o gradskom trošku Viša djevojačka škola u Karlovcu sa šest razreda. Do kraja 1876. godine otvoren je i osmi razred pa je Viša djevojačka škola postala osmogodišnja [10].

Više djevojačke škole imale su važnu ulogu u odgoju i obrazovanju djevojaka srednje građanske klase u drugoj polovici 19. stoljeća. Temelj nastavnih programa viših djevojačkih škola bio je odgoj i obrazovanje budućih dobrih kućanica jer se smatralo da žene primarno moraju biti kućanice, supruge i majke, te su se adekvatno tome obrazovale. Sa školskom godinom 1883./1884., počeo se primjenjivati novi nastavni program za više djevojačke škole u kojemu je smanjen broj sati hrvatskog jezika, zemljopisa, povijesti, računstva i prirodoslovlja. Ženski ručni rad imao je najveću satnicu od 4 sata tjedno u petom i šestom razredu, a 6 sati tjedno u sedmom i osmom razredu [11].

Nakon završetka škole, Jelka Labaš boravi kod roditelja i bake u Karlovcu gdje obavlja radove u domaćinstvu i pohađa privatnu nastavu francuskog, povijesti i geografije [12]. and Vilma baroness Salis-Seewis [5]. Her father's occupation was a clerk. It was noted in her birth certificate that the parents' religion was Roman Catholic, and they lived on the outskirts of Karlovac. She got baptised in April 25, 1886, in the parish of Mary of the Snow in Dubovec. The godfathers at the ceremony were Emanuel pl Vraniczany-Dobrinović, a nobleman from Severin, and his wife Jelena [6]. Jelka was born as the first out of ten children in the family, and she also had two half-siblings from her father's previous marriage. According to the data concerning the place of birth of her sisters and brothers, we can conclude that the family also lived in Samobor, Virovitica, Zeugg, and finally in Varaždin where both of her parents died [7].

Jelka Labaš attended High School for Girls in Karlovac. Concerning the information found in her school reports from the fifth to the eighth grade, it is evident that she lived in Karlovac during her schooling time, on the Zrinjski square. At that time, her father was working as a royal county superintendent in Senj [8]. She graduated from school on June 29, 1901 [9].

In 1873, the High School for Girls had been founded in Karlovac with the permission of the Provincial Government, the Department for Divine Worship and Education. It had six grades. By the end of 1876, the school introduced the eighth grade as well, so that the school then lasted for eight years [10].

Girls' high schools of that time had an enormous role in the upbringing and educating of girls belonging to the middle class during the second half of the $19^{\text {th }}$ century. The curriculum of those girls' high schools at that period was based on bringing up and educating future good homemakers because it was considered that women should primarily be housewives, good mothers, and wives. Therefore, they had education accordingly. During the school year of 1883/1884, the authorities started to apply the new curriculum for girls' high schools, where they had fewer lessons of Croatian, geography, history, counting, and science. The biggest hourly rate had the subject called Female Needlework with four lessons a week during the fifth and sixth grade, and six lessons during the seventh and eighth grade [11].

After graduating, Jelka Labaš stays with her parents and grandmother in Karlovac, where she works in the household and attends the private French lessons, as well as geography and history lessons [12].

At the age of 26, she continues with her schooling in Vienna and on April 15, she was admitted as a student trainee in the Red Cross Hospital Rudolfinerhaus where she was educated for three years for the profession of a nursemaid, being the nurse in fact [13].

She passed her final exams on June 16, 1915 and in the content of her certificate, it was stated that Rudolf's association for building and maintenance gives therefore to the nurse of the Red Cross, the nurse Jelka noble Labaš Blaškovečki, born in Karlovac, Croatia 1889, one of the hospital pavilions in purpose to educate nurses and nursemaids for sick and wounded people in Vienna. She receives her certificate as evidence and proof of her three-year-long education and loyal service as a nurse in the Red Cross Hospital Rudolfinerhaus for the Rudolginer Association [14].

\footnotetext{
${ }^{1}$ Niži administrativni službenik; pisar
} 
U dobi od 26 godina nastavlja školovanje u Beču i 15. travnja 1912. godine primaju je kao učenicu u Bolnicu Crvenog Križa Rudolfinerhaus gdje pohađa trogodišnje obrazovanje za sestru njegovateljicu [13].

Diplomirala je 16. lipnja 1915. godine, a sadržaj diplome navodi "Rudolfovo udruženje za gradnju i uzdržavanje jednog paviljona - bolnice u svrhu izobrazbe njegovateljica bolesnika i ranjenika u Beču podjeljuje ovime sestri crvenog križa: Sestri Jelki pl. Labaš-Blaškovečkoj, rođenoj u Karlovcu, Hrvatska 1886., diplomu kao potvrdu trogodišnje naobrazbe i vjernog službovanja u svojstvu sestre njegovatelja u Bolnici Crvenog Križa Rudolfinerhaus za družbu Rudolfiner-udruženja." [14].

Državni ispit za njegovatelje položila je 6. srpnja 1917. godine u Beču u Allgemeines Krankenhaus. U diplomi se navodi: „...podvrgla (se) strogom ispitu prema propisima Ministarstva unutarnjih djela, s uspjehom položila, te je time dokazala da je sposobna obavljati u praksi zvanje sestre bolničarke. Ona je ovlaštena, da nosi naslov Diplomirane bolničarke, te imade pravo, da vrši svoje zvanje nakon što se je prijavila kod nadležne oblasti." [15].

U razdoblju od 15. travnja 1912. do 31. prosinca 1918. godine radi kao sestra njegovateljica u Rudolfinerhausu. Nakon toga, od 1. siječnja 1919. godine postaje učenica primaljskog zavoda u Rudolfinerhausu i 28. srpnja 1919. godine polaže državni ispit za primalje u Allgemeines Krankenhaus Klinik Piskaček. Dobiva namještenje kao odgovorna sestra i prva primalja na porodnom odjelu u Rudolfinerhausu [16]. Rudolfinerhaus napušta 1920. godine kako bi nastavila rad u Školi za sestre pomoćnice u Zagrebu.

\section{Rad u Školi za sestre pomoćnice u Zagrebu}

Jelka Labaš 3. siječnja 1921. godine predaje zamolbu Zdravstvenom odsjeku za Hrvatsku, Slavoniju i Međumurje u Zagrebu za zaposlenje u Školi za sestre pomoćnice. U to vrijeme voditelj Zdravstvenog odsjeka je dr. Josip Lochert. Uredbom od 27. siječnja 1921. godine Josip Lochert imenuje ju predstojnicom u novoosnovanoj Školi za sestre pomoćnice u Zagrebu „... uz nagradu mjesečnih jednu hiljadu četiristo /=1.400.-/ kruna, te opskrbu u zakladnoj bolnici i stan ili stanarinu". Novo imenovana nadstojnica u svom radu bila je odgovorna ravnatelju škole: „...funkcije koje ćete imati obavljati, odredit će Vam ravnatelj škole, kotarski liječnik Dr. Vladimir Čepulić, kojem ste podredjena,- Škola se osniva na jednu godinu, pa će i Vaše namještenje tako dugo trajati, u koliko se do tog roka ne učini ima kakova odredba u pogledu Vašeg namještenja." [17].

Rješenjem od 26. rujna 1922. godine dr. Lochert postavlja Jelku Labaš učiteljicom s nagradom, odgovarajućom berivima činovnika IX. činovnog razreda kod kr. državne blagajne u Zagrebu [18]. Ministar narodnog zdravlja imenuje ju 28. listopada 1922. godine predstojnicom Kraljevske državne škole za sestre pomoćnice, za što je 27. studenog 1922. godine službeno položila zakletvu [19].

Komisija za ocjenjivanje državnih službenika Inspektorata ministarstva narodnog zdravlja, prema čl. 77. - 80. Zakona o činovnicima i ostalim službenicima građanskog reda, na temelju Starešinskog izvještaja od 9. srpnja 1925. godine ocjenjuje rad Jelke Labaš ocjenom vrlo dobar [20]. Rad dr-
She passed her state exam for a nursemaid on July 6, 1917 in Vienna in General Hospital. It was said in her diploma: ... she has undergone a very strict examination according to the rules and standards of the Ministry of the Interior, she passed the exams with honours, and she has, therefore, proven her ability to carry all the work of a nurse in a hospital. She is certified and entitled to be called a Graduated Staff Nurse and has the right to practice her profession after she is notified within the appropriate jurisdiction [15].

From April 15, 1912, till December 31, 1918, she was working as a nursemaid in Rudolfinerhaus. After that time, from January 1, 1919, she became a student at the Obstetric Institute in Rudolfinerhaus. On July 28, 1919, she took the state exam for midwives in the General Hospital, Clinic Piskaček. There she got the job of a chief midwife, being a rather responsible nurse and the first midwife on the Maternity ward in Rudolfinerhaus [16]. She left the Rudolfinerhaus in 1920 in order to continue her work in School for Nurses in Zagreb.

\section{Her work in School for Nurses in Zagreb}

On January 3, 1921, Jelka Labaš applied, by the Health Department for Croatia, Slavonia, and Međimurje Region in Zagreb, for a job at School for Nurses. The head of the department at that time is Doctor Josip Lochert. By the decree, from January 27, 1921, doctor Josip Lochert appointed her to be the headmistress of the new School for Nurses in Zagreb ....with the monthly salary containing one thousand fore hundred crones /1.400.-/ together with the provisions in Foundation Hospital and accommodations or the rent. The newly appointed headmistress was in her work responsible only to the school principal: All the things you are supposed to do will be delegated by the principal of the school, county doctor Vladimir Čepulić, to whom you are a subordinate. The school is first founded for a year and, therefore, your position will last as long, unless there will be any other kind of decision brought about within the period concerning your employment [17].

According to the resolution from September 26, 1922, doctor Lochert placed Jelka Labaš to be a teacher with reward, the appropriate salary for clerks of IX clerk rank with the State Treasury in Zagreb [18]. The Minister for Public Health appointed her on October 28, 1922, the headmistress of the Royal State School for Nurses, and on November 27, 1922, she officially took the oath [19].

The commission for the evaluation of the state officials functioning within the Inspectorate of the Ministry for the Public Health, according to the paragraph 77-80 of the Law on Clerks and other officials of civic order, based on the Strategic Report from July 9, 1925, describes the work of Jelka Labaš with the grade very good [20]. The work of state officials was evaluated through the following categories: the sort of work done and the accomplishments achieved during the evaluation, specific professional qualifications, the knowledge about medical corps and the nursing profession, the knowledge about public administration's organization, dependability, diligence and tidiness on duty, behaviour on duty and outside of it, together with the evidence about the absence of different vices, fines, and dis- 
žavnih službenika ocjenjivan je u sljedećim kategorijama: vrsta posla i uspjeh u vremenu za koje se provodilo ocjenjivanje, specijalna stručna sprema, opis znanja o sanitetu i struci, znanje o organizaciji državne uprave, pouzdanost, marljivost i urednost u službi, vladanje u službi i izvan nje te navod o postojanju poroka, kazna za neurednost i disciplinske prijestupe, evidencija odsustva i bolovanja.

Tijekom svog rada Jelka Labaš bila je odsutna iz službe zbog bolovanja, od 4. travnja do 20. lipnja 1924. godine, koje je odobrio Zdravstveni odsjek u Zagrebu, te od 5. srpnja do 5. kolovoza 1925. godine što je odobrio Inspektorat ministarstva narodnog zdravlja. Odobrena su joj i dva naučna putovanja. Prvo od 23. srpnja do 23. kolovoza 1924. godine u Varšavu i drugo od 7. do 14. travnja 1925. godine. Za drugo putovanje nije bilo moguće naći podatak o mjestu putovanja [16]. Jelka Labaš napušta školu 1925. godine, ali iz obrađenih arhivskih izvora u HDA-i nije moguće utvrditi točan datum do kada je radila u Školi.

Kako navodi Dugac, sestra Labaš bila je jako predana svom pozivu te je s najvećom ozbiljnošću u školi postavila red $i$ kriterije bliske samostanskim zajednicama koje su njegovale sestrinstvo kao životni poziv, a ne samo kao profesiju [21].

Zanimljiv je i pogled na uniformu koju je sestra Labaš nosila na fotografiji s dodjele diploma prvoj generaciji sestara pomoćnica. Može se vidjeti da, za razliku od civilnih učenica, preko ramena nosi malu pelerinu koja je bila sastavni dio uniforme sestara u Rudolfinerhausu.

Odlaskom Jelke Labaš mijenja se situacija u školi. Prema marginalijama iz sačuvanih zapisa može se pretpostaviti da je samostanska orijentiranost u disciplini sestara bila zamijenjena više svjetovnim načinom organiziranja internata i same škole [21].

\section{Govor Jelke Labaš na 2. konferenciji Društva Crvenog križa u Beču}

O radu Škole za sestre pomoćnice u Zagrebu Jelka Labaš, kao njezina predstojnica, govorila je na 2. Konferenciji Društva Crvenog križa srednje i istočne Europe u Beču koja je održana od 11. do 15. svibnja 1925. godine [22].

$\mathrm{U}$ referatu pod nazivom Bolničko osposobljavanje sestara pomoćnica za društvenu skrb (Ausbildung der fürsorge gemeindesch wester im Krankenhaus), osvrnula se na značaj socijalne medicine i nezamjenjivu ulogu sestara pomoćnica $u$ realizaciji tog projekta. Navodi da uspjeh socijalno-higijenskih ustanova i aktivnosti koje one provode ovise o djelatnosti sestre. Zaključuje da ako se želi poticati i podići zdravlje cijelog naroda na višu razinu, sestra mora djelovati prosvjetiteljski i istraživački, a njezine sposobnosti moraju biti takve da može samostalno djelovati i na područjima gdje liječnik nije stalno prisutan.

Nakon uvodnog izlaganja opisuje razvoj bolničke njege u Hrvatskoj. Ističe da do 1921. godine nije bilo kvalificiranih i školovanih njegovateljica, već su njegu obavljale časne sestre sv. Vinka Paulskog i sestre sv. Križa, kojima je dodjeljivano pomoćno osoblje. Njegu su učile po tradiciji, a unatoč požrtvovnom radu, takvo obrazovanje nije bilo dovoljno za uspješno provođenje njege bolesnika. S obzirom na prisu- ciplinary transgressions, including also the records of absence and sick leaves.

During her services, Jelka Labaš was absent from her work only because of the sick leave from April 4 till June 20, 1924, which had been authorized by the Health Department in Zagreb, along with the absence from June, 5 till August 5, 1925, granted by the Inspectorate of the Ministry for Public Health. She was also allowed two scientific-educational journeys. The first one took place in Warsaw from July 23 to August 23, 1924, and the second was from April 7 till April 14, 1925. It was not possible to find any data where the second journey took place [16]. Jelka Labaš left the school in 1925, but from the processed archived sources in HAD/Croatian National Archives, it was not possible to state until when she worked at school.

As stated by Dugac, nurse Labaš was very dedicated to her profession, and she had, therefore, with the utmost severity installed the order and high standards in the school which were very close to those of monastic communities that taught of nursing as being life calling and not a profession [21].

It is interesting to look at the uniform worn by nurse Labaš on the photo taken during the graduation ceremony for the first generation of the nursemaids. It is visible that, differently from the civilian students, she was wearing a small overcoat which was the consisting part of the nurses' uniforms in Rudolfinerhaus.

With her withdrawal from school, the situation there changed. According to the marginalia of the preserved recordings, it is possible to assume that the monastic orientation concerning the discipline for nurses in school was replaced by the more secular way of organization for the student's dorm and the Boarding School itself.

\section{Jelka Labaš Speech during the second Conference of Red Cross Society in Vienna}

Jelka Labaš talked about the work and function of the School for Nurses in Zagreb at the second conference of the Red Cross Society for middle and eastern Europe in Vienna which was held from May 11 till May 15, 1925 in the role of its headmistress [22].

In her report Hospital training for nurses within social care (Ausbildung der Fürsorgegemeindeschwester im Krankenhaus), she especially stressed the importance of social medicine and the irreplaceable role of nurses and nursemaids in the realization of the project. She also stated that the efficiency of the social-hygienic institution and their activities closely depends upon the work and doings of nurses. She concluded that, if there was a wish to take care of and raise the health situation of the whole population to a higher level, nurses should act educationally and scientifically, and their abilities should be sufficient to work on their own in those cases where a doctor is not continuously present.

After her introductory report, she also described the development of hospital care in Croatia. She underlined that up to 1921, there were no qualified and educated nursemaids. The nuns of St. Vinko Paulski and the nuns of the Saint Cross, 
stvo mnogih bolesti, a pogotovo tuberkuloze, hitno je trebalo osposobiti sestre za skrb o oboljelima od tuberkuloze te je u siječnju 1921. uspostavljena Škola za sestre pomoćnice. Zbog malog broja učenica, moglo im se detaljno posvetiti i u kratkom roku pružiti prilično dobro obrazovanje. Nastavni programi preuzeti su iz drugih država i prilagođavani su kako navodi Labaš, osobitostima naše domovine. Navodi da se osim strukturiranog teorijskog obrazovanja, obavlja i praktično obrazovanje $s$ dva programa: jedan za učenice iz puka koje se većinom obrazuju za sestre pomoćnice, a drugi za učenice redovnice koje se posvećuju općoj njezi bolesnika. Razdoblje školovanja dijeli se na pripremni, prvi, drugi, treći i završni semestar. Tijekom pripremnog semestra koji traje tri mjeseca, dobiva se osnovno teorijsko obrazovanje u predmetima: Fizika, Kemija, Biologija, Anatomija i fiziologija, Povijest, Osnovni pojmovi i tehnike njege bolesnika s prikazom i praktičnim vježbama u kabinetu za vježbe, kako bi učenice bile upućene u osnove na kojima se temelji njega bolesnika. Nakon završetka pripremnog semestra učenice polažu ispit i spremne su i osposobljene za nadolazeća iskustva i poteškoće s kojima se susreću već početkom praktičnog rada u bolnici, a koji je za sestre od najvećeg značaja. U nastavku školovanja, tijekom prvog i drugog semestra, učenice rade na kirurškim i internističkim odjelima, uče provođenje elektroterapije i hidroterapije te vježbaju izvođenje pretraga mokraće, iskašljaja, želučanog soka i krvi, koje su savladale u teorijskoj nastavi. Učenice se raspoređuju u operacijske dvorane, ambulante i jedinice hitnog prijema ozlijeđenih, rade u zaraznoj bolnici, u ginekološkom odjelu i rađaoni, raspoređuju se u laboratorij, na očni odjel i u ambulantu za bolesti oka kako bi naučile prepoznavati i provoditi zbrinjavanje oboljelih od trahoma kojih ima mnogo. Nadalje, u svom govoru ističe kako je za sestru važna njega djeteta, zdravog i bolesnog, te prehrana djece. Budući da nema prikladnih odjela, školovanje iz tih područja provodi se u dječjoj ambulanti, na odjelu za dojenčad, u savjetovalištu za majke, mliječnoj kuhinji i školskoj poliklinici. Također ističe da je tijekom školovanja iznimno važno pažnju učenica usmjeriti na razne metode improvizacije prikladne njihovom poslu, s obzirom na potrebu rada u udaljenim područjima gdje nema potrebnih objekata za bolesnike.

Paralelno s praktičnim radom tijekom prvog i drugog semestra, provodi se i teorijska nastava. U prvom semestru slušaju se predmeti Opća patologija, Bakteriologija i farmakologija, Kirurgija, Interna medicina i dijetetika, a u drugom semestru Pedijatrija, Zarazne bolesti, Ginekologija, Porodništvo i poslijeporođajna njega, Neurologija, Psihijatrija i fizikalna terapija. U trećem semestru, uz praktični rad u socijalno-higijenskim ustanovama, učenice slušaju predavanja iz Higijene, Socijalne medicine, Organizacije javnog zdravstva i zakonodavstva. Uče o uzrocima socijalnih oboljenja s naglaskom na tuberkulozu, malariju, alkoholizam, parazitske bolesti, spolne i bolesti kože te o protuepidemijskim mjerama. Završni semestar posvećen je isključivo radu u socijalno-higijenskim ustanovama nakon kojega se polaže državni ispit. Nakon toga sestre se raspoređuju na područje budućeg rada. U svom izlaganju Jelka Labaš opisuje da istu školu pohađaju i sestre redovnice što zasigurno ima prednosti jer pridonosi međusobnom razumijevanju u radu. Na taj način, sestra je upućena u socijalno-higijenski pristup i u which were assisted by support staff, took care for patients. Nursing was learned by tradition and, although they worked most devotedly, that kind of education was insufficient for the successful realization of patient care. Taking into consideration that there were many illnesses present among people, especially tuberculosis, the urgent need for education of nurses who would care for tuberculosis-infected patients occurred. Therefore, the school for nurses and nursemaids was founded in January 1921. Owing to the small number of female students, it was possible to teach them individually and give them high-quality education in a rather short time. School curricula were taken from similar schools abroad and were adapted according to Labaš to the particularities of our homeland. She also said that, along with the structuralized theoretical education, there is practical training with two possibilities: the first for students originating from common people who were mostly educated for nursemaids and the second for students who were nuns and mostly dedicated themselves to the general care of the patients. The duration of schooling was divided into preparatory, the first, the second, the third, and the concluding semester. During the preparatory semester, which lasted for three months, students gained basic theoretical knowledge in subjects like physics, chemistry, biology, anatomy, and physiology, history, main terminology, and techniques in nursing, together with the theory and practical training in the training cabinets. It was all done with the purpose of acquiring the basics for the efficient patient care. When they finished the preparatory semester, the students took an exam and were afterwards ready and qualified for the upcoming work experience and the difficulties they will probably face at the very beginning of their real duties in hospitals, but which carries the outmost meaning for the nurses. While extending their education, during the first and the second semester the students work on surgical and intern wards, they learn how to do electrotherapy and hydrotherapy and they also practice how to examine urine, mucus, stomach juices, and blood, which they had already learned in the theoretical part of their studies. Students are sent to operating rooms, clinics, and emergency units for admitting the injured, they work in Centre for Disease Control, gynaecology clinics, and delivery rooms, in laboratories, at ophthalmology wards and clinics in order to learn how to recognize and perform care for those suffering from trachoma. She further underlined that, for every nurse, baby care represented great importance, the care for a healthy and a sick baby likewise, as well as the children nutrition. Since there weren't any appropriate wards for children in hospitals, the education concerning those fields was conducted in children's clinics, on the wards for infants, in counselling centres for mothers, dairy kitchens, and school clinics. She also pointed out that, during their schooling, students should be thought with the biggest importance how to develop different methods of improvisation necessary for their job, taking into consideration the need of work in remote areas without any sufficient facilities for the sick.

In parallel with the practical training during the first and second semester, theoretical classes were held as well. Within the first semester, they attended subjects such as pathology, bacteriology and pharmacology, surgery, in- 
mogućnosti je već u bolnici raditi s bolesnikom na njegovu zdravstvenom odgoju i obrazovanju. Jedinstvo teorijskog obrazovanja omogućuje da sestra bolničarka, ako poželi, može nakon završene desetomjesečne prakse u različitim socijalnim ustanovama dobiti diplomu sestre pomoćnice, a sestra pomoćnica može po završetku desetomjesečne prakse na različitim bolničkim odjelima dobiti diplomu bolničke sestre.

U završnom dijelu svog govora ističe da je: „od neizmjerne važnosti da sestre, kojima je povjerena tako odgovorna zadaća, budu na što je moguće većoj etičkoj razini, tako da u praksi ne djeluju samo riječima nego i da budu dobar primjer," [22].

\section{Odlazak u Družbu Kćeri Božje ljubavi}

Jelka Labaš 2. veljače 1930. godine odlazi u samostan Družbe Kćeri Božje ljubavi u Novoj Vesi u Zagrebu te dobiva ime Marija Augustina. U novicijat ${ }^{2}$ stupa 5 . kolovoza 1930. godine. Prve zavjete polaže 15. kolovoza 1932., a vječne zavjete 28. kolovoza 1936. godine.

Postavljena je za prefektu (predstojnicu) u internatu Učiteljske škole Zavoda sv. Josipa u Sarajevu 16. kolovoza 1931. i istovremeno predaje Higijenu u Učiteljskoj školi te u istoj školi obavlja službu sestre bolničarke. U Zagreb se vraća 1933. kao prefekta Državne stručne kućanske škole, a 1934. premještena je u Dom presvetog Srca u Koprivnici. Kao sestra bolničarka od 1935. godine radi u Milni da bi 1937. bila premještena u Postire gdje je bila kućna predstojnica i u istom svojstvu 1938. godine premještena je u Novo Selo. ${ }^{3}$ U Državni dječji dom u Jastrebarskom dolazi 1939. i u Oroslavje je premještena 1941. godine. Za kućnu predstojnicu dolazi u Langov Dom u Zagrebu 1942. godine. Ponovno se vrača na Brač u Supetar (1947. godine) i Postire (1948. godine). Rješenjem od 14. kolovoza 1951. godine odlazi u mirovinu za koju joj je priznato 15 godina, 10 mjeseci i 15 dana rada. Jelka Labaš umrla je 30. kolovoza 1962. godine u Splitu gdje je i pokopana [24].

\section{Zaključak}

Jelka Labaš prva je sestra nadstojnica u Školi za sestre pomoćnice u Zagrebu koja je počela s radom u siječnju 1921. godine. Škola za sestre pomoćnice otvorena je zbog potrebe osposobljavanja i educiranja zdravstvenog osoblja u cilju sprečavanja i suzbijanja tuberkuloze koja je u to doba bila vrlo raširena i predstavljala je velik zdravstveni i socijalni problem. Kao vodeća osoba u školi, Jelka Labaš zalagala se za organizaciju sestrinstva po uzoru na Rudolfinerhaus i organizaciju nastavnih baza na bolničkim odjelima gdje bi učenice mogle obavljati vježbovnu nastavu. Obrazovanje i iskustvo koje je stekla radeći u Rudolfinerhausu u Beču primjenjivala je u izobrazbi sestara pomoćnica. tern medicine and dietetics, and during the second semester, they had subjects like paediatrics, infectious diseases, gynaecology, obstetrics and post-natal care, neurology, psychiatry, and physical therapy. Alongside their practical training during the third semester, which is done in socialhygienic institutions, students also attended lectures on hygiene, social medicine, public health organization, and legislation. They learned about the causes of social diseases with the emphasis on tuberculosis, malaria, alcoholism, parasitic diseases, genital and skin diseases, and they also learned about applicable counter-epidemiological measures. The final semester was dedicated exclusively to work in social-hygienic institutions, after which they took the state exam. After passing the exam, the nurses were deployed in the area of their future work. In her speech, Jelka Labaš also said that the same school is being attended by nuns who wanted to become nurses which carries its advantages adding to the mutual understanding while performing the duties. In that way, the nurse was informed about the social-hygienic approach and the options at hand because, in the hospital, she works with the patient and tries to educate and enlighten the patient about health care. That kind of unique integrated theoretical schooling enables nurses from hospitals, according to their wishes and after tenmonths-long training done in different social institutions, to get the degree of nursemaids. Furthermore, nursemaids after ten months of training on different hospital wards can get the diploma of a hospital nurse.

In the finishing part of her speech, she underlined the following: it is of the outmost importance that the nurses who have been given such a big responsibility should possess the highest ethical standards so that they in their practical work should be an example to others both by their words and their deeds [22].

\section{Joining the Convent of the Secret Heart/ Congregation of Daughters of God's Love}

On February 2, 1930, Jelka Labaš left for the Congregation of Daughters of God's Love in Nova Ves, Zagreb, and got the new name of Maria Augustina. Into the Novitiate', she arrived on August 5, 1930, and she took her first oaths on August 15, 1932, and finally, she did her eternal vows on August 28, 1936. She was appointed the Prefect (prioress/ principal) in the boarding school for teachers owned by the Institute of Saint Joseph in Sarajevo on August 16, 1931, where she, at the same time, taught hygiene to the students and also acted as a school nurse. She returned to Zagreb in 1933, holding the position the perfect for the State Professional Domestic School, and in 1934, she was transferred to the Home of the Sacred Heart in Koprivnica. From 1935, onwards she worked as a nursemaid in Milna, and in 1937, she was again moved to Postire where she worked as

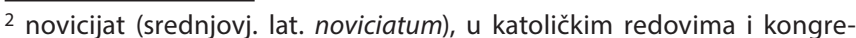
gacijama, pokusni rok kušnje i priprave za redovničko zvanje koje treba provesti u određenoj kući pod vodstvom magistra (učitelja, odgojitelja); redovito traje godinu dana (23)

${ }^{3}$ Novo Selo (Selca), naselje u općini Selca, na Braču
}

\footnotetext{
1 novitiates (middle-aged Latin noviciatum), within Catholic orders and the congregations represents the trial period for the temptation and preparation for the consecrated life that should be spent in a particular order under the supervision of the magister (teacher, educator); it normally lasts for a year [23]
} 
Osnutak Škole za sestre pomoćnice u Zagrebu predstavljao je početak profesionalizacije sestrinstva [4], a Jelka Labaš svojim je radom doprinijela organizaciji škole u prvim godinama njezina djelovanja.

Za šire razumijevanje njezina rada nakon odlaska iz škole u Družbu Kćeri Božje ljubavi bilo bi potrebno dodatno istražiti pismohranu Družbe.

\section{Zahvala}

Autorice zahvaljuju dr. sc. Dariji Hofgraff iz Hrvatskog državnog arhiva na pomoći u pregledu arhivske građe. Nadalje, zahvaljuju za pomoć u prikupljanju arhivske građe iz Državnog arhiva u Karlovcu Snježani Mirilović i iz arhiva Provincije Božje providnosti Družbe Kćeri Božje ljubavi Marinu Čargu i Damjanu Abou Aldanu.

\section{Nema sukoba interesa}

a house superintendent. Same year, she transferred to Novo Selo ${ }^{2}$ carrying the same function. She arrived to Jastrebarsko into the State Orphanage in 1939 and in 1941, she was moved to Oroslavje. She returned to Zagreb into the Lang's Home as the house superintendent in 1942. After that, she went to the island of Brač in the city of Supetar (1947) and Postire (1948). According to the formal solution dating from August 14, 1951, she was retired after 15 years, ten months and 15 days of recognised services. Jelka Labaš died on August 30, 1962 in Split where she was buried as well [24].

\section{Conclusion}

Jelka Labaš was the first nurse superintendentin the School for Nurses in Zagreb. She started her work in January 1921. The School for Nurses was founded because of the need to enable and educate healthcare professionals to prevent and fight against tuberculosis which was, at that time, widely spread and represented an enormous social and health problem. As the leading professional in the school, Jelka Labaš was trying to organize nursing according to the models from Rudolfinerhaus and she also tried to organise the schooling and training due to the curriculum on the hospital wards for all the students. The education, knowledge, and experience she gained working in Rudolfinerhaus in Vienna, constantly applied in teaching nursemaids. The founding of the School for Nurses in Zagreb has marked the very beginnings of the professionalization of nursing [4]. Jelka Labaš, through her work, contributed to the organization of the school in its first years of existence. For the broader understanding of her activities after she left the school and joined the Congregation of Daughters of God's Love, it is necessary to further investigate the convent's archives and records.

\section{Acknowledgements}

The authors would like to thank Darija Hofgraff, PhD, from the Croatian State Archive for her help while researching the archive materials. They also thank Snježana Mirković for the assistance and help in collecting the archive materials from the State Archive in Karlovac, and to Marin Čargo, together with Damjan Abou Aldan from the archive in the Province of the Divine Providence, the congregation of Daughters of God's Love.

\section{Authors declare no conflict of interest}

\footnotetext{
${ }^{2}$ Novo Selo (Selca), a community in the municipality Selca, the island of Brač
} 


\section{Literatura}

[1] Dugac Ž. Protiv bolesti i neznanja - Rockefellerova fondacija u međuratnoj Jugoslaviji. Zagreb; Srednja Europa: 2015.

[2] Belicza B, Dubravko Orlić D. Hrvatski liječnički zbor Predsjednici od 1874. do 2004. Zagreb; Hrvatski liječnički zbor: 2004

[3] HR-HDA-890. Zbirka personalija, Službenički list dr. Vladimira Čepulića

[4] Hoffgraf D, Franković S. Osnutak škole za sestre pomoćnice 1921. 1922. Arh. vjesn. 2017;60: 165-84

[5] Wilhelmine, Barbara Maria Labaš - Blaskovečki rođ. Salis-Seewis (1859- 1922.) dostupno: https://www.myheritage.com.hr/names/ barbara_salis-seewis. učitano: 3. 7.2021.

[6] HR-HAD-890, Zbirka personalija, Jelka Labaš, Krsni list iz matice krštenih župe sv. Marije Snježne u Dubovcu svez. 29. str. 119. br. 53.

[7] Geni. Jelka (Jelena) pl. Labaš Blaškovečka. Dostupno: https://www. geni.com/people/Jelka-Jelena-pl-Laba\%C5\%A1-Bla\%C5\%A1kove\%C 4\%8Dka/6000000045045422821 učitano: 4. 7. 2021.

[8] HR-DAKA-228 VIŠA DJEVOJAČKA ŠKOLA KARLOVAC Ispitna izvješća više djev. Škole od 1896./7. do 1900/01. VII razred šk.godine 1899./1900 pl. Labaš Jelka (knj.br.7)

[9] HR-HAD-890, Službenički list, Jelka Labaš, podaci upisani u rubriku XII.

[10] Vrbetić M. Karlovačko školstvo od 1860 do 1945. u zatezalo Đ, Majetić T, Miholović K. Karlovac; Historijski arhiv u Karlovcu: 1979. 459-72.

[11] Župan D. Dobre kućanice - Obrazovanje djevojaka u Slavoniji tijekom druge polovice 19. stoljeća, Scrinia Slavonica 2009;9: 232-56.

[12] Kovačević T, Glavaš T. Jelka pl. Labaš u Kolling, H., Biographisches Lexikon zur Pflegegeschich , Who was who in nursing history, Nidda hpsmedia.

[13] HR-HAD-890, Službenički list, Jelka Labaš, podaci upisani u rubriku $\mathrm{XVI}$.
[14] HR-HAD-890, Zbirka personalija, Jelka Labaš, Duplikat velike diplome, izdano od Družbe Rudolfiner-udruženja

[15] HR-HAD-890, Zbirka personalija Jelka Labaš, Prijepis Diplome sestre bolničarke, izdano od Ispitnog povjerenstva na Bolničarskoj školi sveopće bolnice u Beču

[16] HR-HAD-890, Službenički list, Jelka Labaš

[17] HR-HAD-890, Zbirka personalija Jelka Labaš, Prijepis rješenja br. 8591921.

[18] HR-HAD-890, Zbirka personalija Jelka Labaš, Prijepis rješenja br. 27.471-1922.

[19] HR-HAD-890, Zbirka personalija Jelka Labaš, Prijepis Rješenja br 32.664-1922.

[20] HR-HAD-890 Zbirka personalija Jelka Labaš, Starešinski izvještaj

[21] Dugac,Ž. O sestrama, siromašnima i bolesnima: slike socijalne i zdravstvene povijesti međuratnog Zagreba, Zagreb, Srednja Europa (2015), 9 (24., 25.)

[22] Jelka von Labas. Ausbildung der fürsorge gemeindesch wester im Krankenhaus. Liga der Rotkreuzgesellsxchaften, Zweite Konferenz der Rotkreuzgesellschaften von Mittel und Osteuropa. Wien 11-15. Mai 1925. Komision für pflegewesen (IV. Kommission) Berüssungsansprachen berichte. str. 93-99. (prijevod originalnog teksta Tanja Glavaš) izvor: Zbirka povijesti sestrinstva HUMS-a.

[23] Hrvatska enciklopedija, mrežno izdanje. Novicijat. Leksikografski zavod Miroslav Krleža. dostupno: http://www.enciklopedija.hr/Natuknica.aspx?ID=44264 Pristupljeno: 9. 7. 2021.

[24] Arhiv Provincije Božje providnosti Družbe Kćeri Božje ljubavi - osobn podaci sestara 